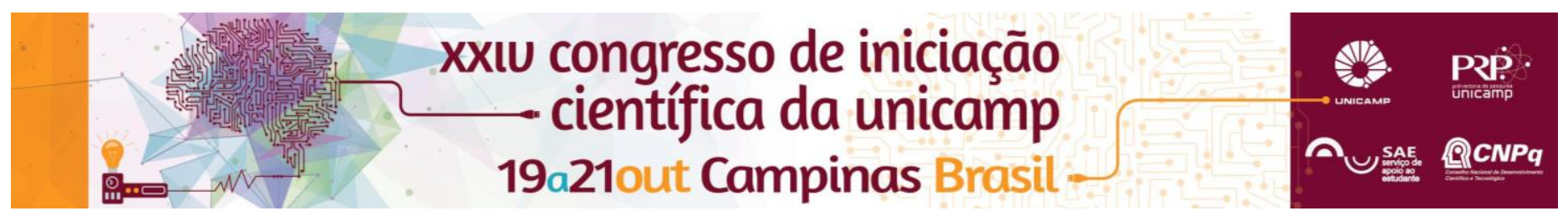

\title{
Escolarização de crianças Surdocegas sob a percepção dos pais e/ou responsáveis.
}

\author{
"Mayara G. Toffoli" e Maria E. F. Gasparetto.
}

\section{Resumo}

Pretende-se com este trabalho, desvendar a percepção de pais e/ou responsáveis, a respeito do processo de escolarização de alunos com surdocegueira, por meio de uma abordagem de caráter qualitativo, realizando-se por meio da aplicação de questionário pré-elaborado. Concluímos que a maior dificuldade por parte dos indivíduos se dá pelo aspecto abstrato da alfabetização, além da dificuldade na compreensão da capacidade real dos filhos surdocegos em relação à escolarização e alfabetização.

\section{Palavras-chave:}

Escolarização, Surdocegueira e Fonoaudiologia

\section{Introdução}

Levando em conta o termo: "letramento emergente", que são todos os contatos que uma criança tem com a palavra escrita em sua vida desde 0 nascimento, rótulos de embalagens, marcas de produtos, nomes de lojas, comerciais de televisão, livros infantis, jornais, revistas e toda uma variedade de materiais que possam levar a criança à convivência com o mundo da leitura e escrita, devemos pensar em como uma criança que é privada de tais estímulos, lidará com o fato de ter que aprender algo que para ela não faz nenhum sentido, pois não é concreto. Um fator que trará o sucesso da alfabetização / letramento é o domínio da linguagem. A criança terá mais sucesso nesse processo se ele se der levando em conta seu universo social e cultural, a criança precisa falar - ouvir - escrever sobre eventos de seu diaa-dia, de objetos, de ações que tem conhecimento e vivência, desta forma, evidencia-se a importância da família neste processo, uma vez que, a criança permanece por mais tempo com a família do que na instituição. Em relação ao uso do Implante Coclear, este é utilizado em sujeitos surdocegos com o objetivo de estimular a audição residual, sendo assim, sua única fonte de contato com o meio externo e as pessoas. Tivemos por objetivo desvendar a percepção de pais e/ou responsáveis, a respeito do processo de escolarização de alunos com surdocegueira.

\section{Resultados e Discussão}

Após análise dos dados, percebemos o grande déficit na educação de sujeitos com surdocegueira, uma vez que, as escolas apesar de aceitarem, não possuem estrutura necessária para desenvolver um projeto com estes alunos.

Os sujeitos com este tipo de comprometimento tem sim capacidade de adquirir os conceitos necessários para a alfabetização, porém, os pais por não conhecerem o trabalho que deve ser realizado, acreditam não ser possível a um sujeito surdocego, ler e/ou escrever, o que transforma a aquisição da linguagem deste sujeito muito restrita.

Os profissionais da educação, por outro lado, apesar de saberem das capacidades da criança, não são capacitados a atender pacientes com estas deficiências, ou seja, apesar de toda a boa vontade entusiasmo dos mesmos, não é possível que estes realizem um projeto efetivo de alfabetização.

Escolas particulares se mostraram melhor adaptadas e com mais opções de recursos para estes alunos, contando com salas de recursos especiais, professores capacitados e materiais de alta tecnologia, porém, as escolas estaduais e municipais, demonstraram falta de recursos, ausência de professores capacitados e pouca quantidade de professores, o que faz com que os alunos tenham apenas um professor por sala.

\section{Conclusões}

Concluímos, portanto, que as novas tecnologias podem trazer muitos benefícios aos sujeitos surdocegos no que se refere à alfabetização dos mesmos, porém, para que isto aconteça, é necessário que os profissionais da educação recebam um treinamento específico para poderem abordar da melhor maneira possível este tema com estes sujeitos. Devemos inferir ainda, que os pais e/ou responsáveis, devem ser orientados adequadamente a respeito das capacidades reais de cada sujeito, para assim, conseguirem colaborar no processo de letramento de seus filhos.

\section{Agradecimentos}

Agradeço à Prof ${ }^{a}$ Maria Elisabeth, pelas horas de trabalho e dedicação ao projeto.

ETHERIDGE, D. The Education of Dual Sensory Impaired Children. London: David Fulton Publishers Ltd, 1995, p. 9-18.

GALVÃO, N. C. S. S.; MIRANDA, T. G. Atendimento educacional especializado para alunos com surdocegueira: um estudo de caso no espaço da escola regular. Rev. bras. educ. espec.vol.19 no.1 Marília Jan./Mar. 2013.

Disponível em: http://dx.doi.org/10.1590/S1413-65382013000100004.

MILES, B., Alfabetização de pessoas surdocegas. Título Original: Alfabetización de lãs personas que son sordas y invidentes. DB-LINK - La Oficina Central de Información Nacional sobre los Niños que son Sordociegos. Janeiro/2000. Tradução: Miriam Xavier - Revisão: Shirley Rodrigues Maia/2007. Projeto Horizonte - Ahimsa/Programa Hilton/Perkins. 